\author{
ACTA MYCOLOGICA \\ Vol. 46 (2): 233-244 \\ 2011
}

\title{
Freshwater lichens on submerged stones and alder roots in the Polish lowland
}

\author{
MARIUSZ HACHUŁKA
}

\author{
Department of Mycology, Laboratory of Lichenology \\ University of Łódź, Banacha 12/16, PL-90-237 Łódź, m.hachulka@poczta.fm
}

Hachułka M.: Freshwater lichens on submerged stones and alder roots in the Polish lowland. Acta Mycol. 46 (2): 233-244, 2011.

The article presents the results of the studies of lichens in streams and spring areas of the escarpment zone of Wzniesienia Łódzkie Heights in Central Poland. The boulders, stones and roots of Alnus glutinosa, situated in 3 inundated zones in the streams: submerged zone, fluvial mesic zone and fluvial xeric zone, were examined in the streams. The studies have shown 23 species connected with these streams. Six species of freshwater lichens: Verrucaria aquatilis, V. hydrela, Hydropunctaria rheitrophila, V. margacea, V. praetermissa and V. madida, occupied stones in 3 different zones. Verrucaria aquatilis and Hydropunctaria rheitrophila colonized also secondary substrates - the bark of alder roots incrusted with sand grains and silt.

Key words: aquatic lichens, freshwater habitats, stone and tree root substrates, Central Poland

\section{INTRODUCTION}

In Europe studies of epilithic freshwater lichens and their ecology have been carried out for over a hundred years. A pioneering paper indicative of the zonal distribution of lichens by Santesson was published in 1939. The author was the first to notice that not only a substrate has an effect on the structure of aquatic lichen groups, but also the time of thallus flooding (Coste 2010, after Santesson 1939).

The best so far examined water habitats in England have shown that on all of the localities the lichen species are found in the form of series of overlapping streaks connected with the duration and altitude of flooding, which Gilbert (1996) called zones and distinguished 4 of them: 1 - submerged zone, 2 - fluvial mesic zone, 3 - fluvial xeric zone and 4 - fluvial terrestrial zone. At first, these zones were distinguished on the basis of studies of rivers flowing on cretaceous formations and limestones and later they were confirmed in rivers flowing on acid rocks (Gilbert, Giavarini 1997; Hawksworth 2000). 
Coste (2010), while he was examining freshwater lichens in France distinguished 3 zones: hyper-hydrophilic lichens, meso-hydrophilic lichens and sub-hydrophilic lichens. In Poland, mainly, montane and submontane streams and rivers were examined, however zonal distribution of lichens was rarely distinguished, e.g., the submerged zone and the splash zone (Krzewicka, Galas 2006; Krzewicka 2009). Kiszka (1998) while he was examining lichens in the Czarna Wisełka and Biała Wisełka catchments distinguished 2 zones: the zone of stream bed and the zone of stream banks. In these habitats he noted 73 epilithic taxa, including lichens directly connected with water habitat of streams and spring areas.

In relation to the species composition and the distribution of freshwater lichens growing on stones and boulders, the areas of the Western and Eastern Carpathians are the best known. In the montane streams of the Polish part of the Carpathians the studies of freshwater lichens were carried out by Kiszka $(1995,1998)$, Krzewicka (2006, 2009), Krzewicka and Galas (2006). Occasional data can be found in the papers by e.g., Nowak (1965, 1998), Kiszka (1967, 1985, 1996, 1997, 2000), Nowak and Tobolewski (1975), Kozik (1977), Czarnota (2000), Kiszka and Kościelniak (2001), Bielczyk (2003), Kościelniak and Kiszka (2003), Kościelniak (2004), Flakus (2007), Śliwa (2010). The records of Verrucaria dolosa and V. hydrela from the Sudety Mountains (Masyw Śnieżnik Massive and Góry Bialskie Mts) were given by Szczepańska (2008). All of the authors paid attention mostly to epilithic species of the genus Verrucaria (Hydroverrucaria).

The freshwater lichens in the Polish lowlands are very poorly known. A few data originate mainly from northern Poland (Fałtynowicz et al. 2000; Kukwa 2000; Lipnicki 2002; Fałtynowicz 2003; Fałtynowicz, Kukwa 2006; Szymczyk 2007; Szymczyk, Zalewska 2008), north-eastern Poland (Czyżewska et al. 2001, 2002) and Central Poland - Wyżyna Wieluńska Upland (Nowak 1967) and Wzniesienia Łódzkie Heights (Hachułka 2007; Krzewicka, Hachułka 2008).

Rivers and streams in the lowland differ from montane streams in substrate of their bottom, built mainly of sand and gravel and their banks are most often overgrown by black alder (Alnus glutinosa) and willows (Salix spp.), which are the components of the streamside alder-ash forest. The alder roots growing directly over the river banks are washed by the flowing water, which deposits grains of sand mixed with silt on these tree roots. The bark of alder roots incrusted with grains of sand glued together with silt makes them similar to the rock substrate and, beside the granite stones, it also constitutes the substrate settled by epilithic freshwater lichens.

The paper presents freshwater lichens poorly known or overlooked in the Polish lowlands growing on the rock substrate and on the roots of trees immersed in water. It is an attempt by show their zonal distribution in freshwater habitats exemplified by the streamsides situated in the area of the escarpment zone of Wzniesienia Łódzkie Heights in Central Poland, which is as a whole under legal protection as Wzniesienia Łódzkie Landscape Park. 


\section{STUDY AREA}

The habitats where freshwater lichens are found are present at the Wzniesienia Łódzkie Landscape Park. The objects of research were spring areas and rivers belonging to the Vistula's catchment area (Kondracki 2000). The studies were carried out in the spring part of the Bzura river and its tributaries: Mrożyca, Grzmiaca and Kamienna, and Moszczenica with a tributary - Młynówka (Fig. 1). These streams are similar in character to upland rivers. The maximum height difference reaches 100 metres in the upper catchment of Moszczenica stream (Moniewski 2004).

The substrate has an influence on these rivers water chemistry. The boulder clay, gravels and moraine sands make a large contribution to building the river beds. The river bed is often stony with numerous boulders. In relation to chemistry the waters were best examined in Młynówka stream (Ziułkiewicz 1999; Walisch 2007; Ziułkiewicz, Żelazna-Wieczorek 2007a, b). In relation to physicochemical properties they correspond to the values of hydrochemical setting of groundwaters. They are freshwaters, of middling hardness ranging from weakly acidic to slightly alkaline $(\mathrm{pH}$ 6.46 to 7.47); a reaction based on the contribution of diatoms indicates the alkalinity of water. The hydrochemical values of water are little unstable, they are mineralized to slight degree $\left(0.1-0.5 \mathrm{~g} / \mathrm{dm}^{3}\right)$. A certain changeability of the hydrochemical values results from seasonality and surroundings (forest and field springs). The large contribution of the diatoms demanding high saturation of oxygen in water was noted.

Selected physicochemical features of Kamienna and Grzmiaca streams were examined (Tab. 1). The studies showed the similarity of some features of streams: their

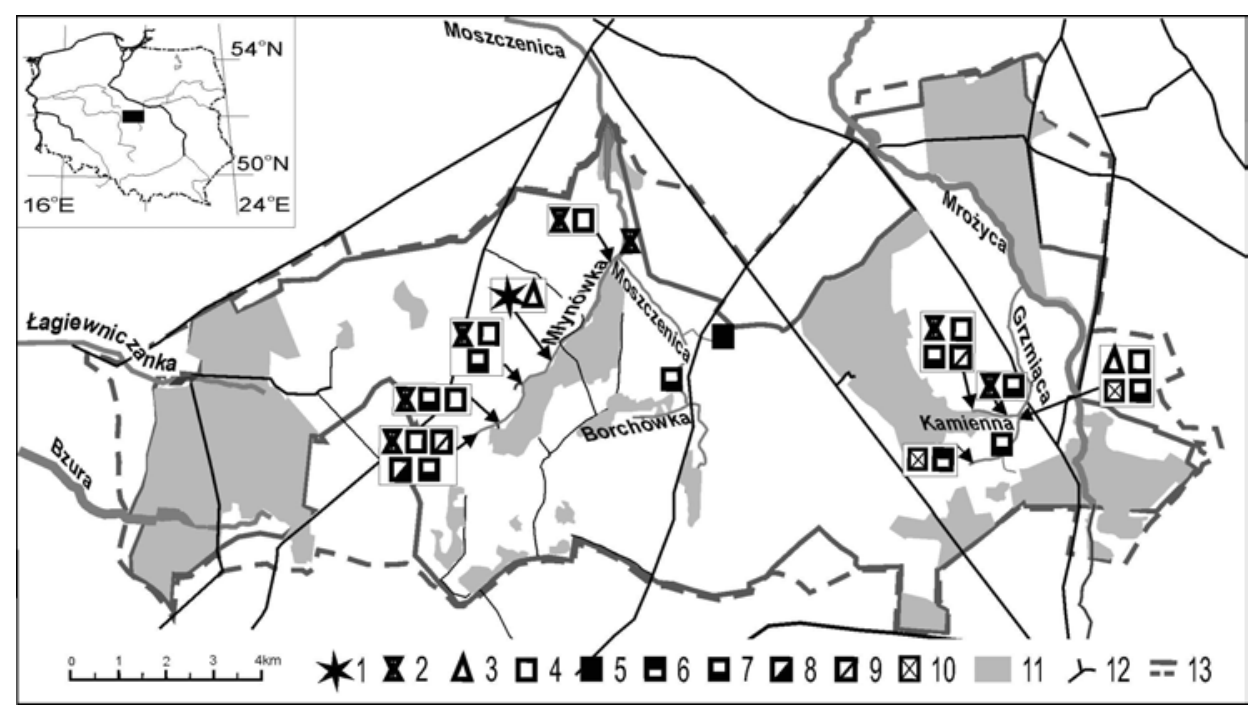

Fig. 1. Distribution of some lichen species growing in streams: 1 - Bacidina inundata, 2 - Hydropunctaria rheitrophila, 3 - Thelidium aquaticum, 4 -Verrucaria aquatilis, 5 - V. dolosa, 6 -V. funckii, 7 -V. hydrela, 8 -V. madida, 9 -V. margacea, 10 - V. praetermissa; 11 - forest area; 12 - roads; 13 - borders of the Wzniesienia Lódzkie Landscape Park. 
Table 1

Physicochemical features of the streams Kamienna and Grzmiąca at the sites of the lichens collection

\begin{tabular}{|l|c|c|c|}
\hline \multicolumn{1}{|c|}{ Feature } & \multicolumn{3}{|c|}{ Streams } \\
\cline { 2 - 4 } & Kamienna & $\begin{array}{c}\text { Grzmiąca } \\
\text { spring part }\end{array}$ & $\begin{array}{c}\text { Grzmiąca } \\
\text { in Tadzin* }\end{array}$ \\
\hline Cross-section surface $\left[\mathrm{m}^{2}\right]$ & 0.10 & 0.11 & 0.17 \\
\hline Hydrometric profile width $[\mathrm{m}]$ & 1.05 & 1.55 & 2.78 \\
\hline Average depht $[\mathrm{m}]$ & 0.05 & 0.07 & 0.07 \\
\hline Maximal depht $[\mathrm{m}]$ & 0.09 & 0.12 & 0.09 \\
\hline Average water velocity $[\mathrm{m} / \mathrm{s}]$ & 0.22 & 0.16 & 0.31 \\
\hline Maximal water velocity $[\mathrm{m} / \mathrm{s}]$ & 0.80 & 0.11 & 0.19 \\
\hline Flow value $\left[\mathrm{m}^{3} / \mathrm{s}\right]$ & 0.02 & 0.01 & 0.05 \\
\hline Water temp. $\left[{ }^{\circ} \mathrm{C}\right]$ & 10.2 & 11.0 & 11.6 \\
\hline pH & 7.41 & 7.70 & 7.70 \\
\hline Oxygen $[\mu \mathrm{m} / \mathrm{cm}]$ & 9.44 & 9.01 & 9.01 \\
\hline Saturation $[\%]$ & 85.8 & 83.3 & 85.1 \\
\hline
\end{tabular}

*2,3 kilometers down the river

average depth, temperature, similar reaction. A higher content of oxygen in the water was found in the Kamienna stream.

The waters of high quality (Ib class) predominate in the majority of the springs, although individual cases of II and III class can also be found (Moniewski 2004).

\section{MATERIAL AND METHODS}

The studied material was the lichens growing in freshwater habitats on siliceous boulders and stones lying in the river and stream beds and on the alder roots and bottoms of trunks growing on the streamsides. The studies were carried out from 2004 to 2008 and in 2011 using the point-based method taking 3 submersion zones into consideration (cf. Gilbert, Giavarini 1997; Hawksworth 2000): 1 - submerged zone (zone with stones and tree roots always submerged in water); 2 - fluvial mesic zone (zone often inundated, with stones and tree roots submerged during the rainfall season); 3 - fluvial xeric zone (zone sporadically inundated, with stones and tree roots submerged or splashed water sporadically, for example during long-lasting rainfall season) - see Figure 2.

Physicochemical measurements of Kamienna and Grzmiaca streams were made by Dr. Zbigniew Kaczkowski and the author in September 2011 (Tab. 1). The studies were carried out using the float method (Bujakiewicz-Grabowska, Magnuszewski 2002) in the site of the collection of lichens samples. Temperature of water, $\mathrm{pH}$, saturation and oxygen in water were also measured.

The lichen materials were identified by routine lichenological methods, imploying a Nikon SMZ 645 and a Nikon Eclipse 80i light microscope, and spot reactions. Lichen nomenclature follows mainly Smith et al. (2009), Diederich et al. (2011), for species Hydropunctaria, Verrucaria and Thelidium - Gueidan et al. (2009), Thüs and Schultz (2009), for Bacidina sulphurella - Hauck and Wirth (2010), bryophyte 


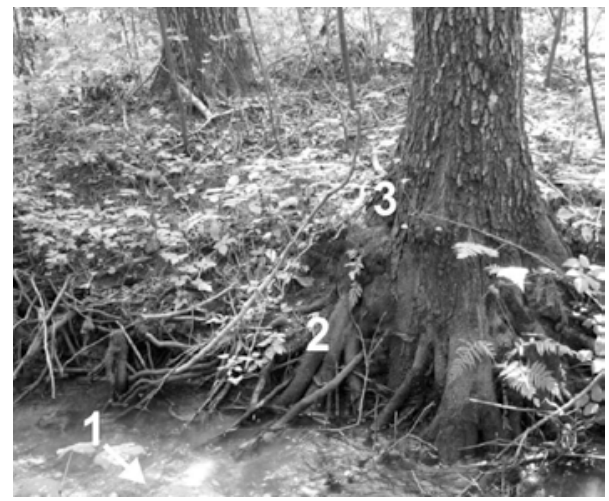

Fig. 2. Distinguished zones for the studies of the lichens in streams: 1 - submerged zone; 2 - fluvial mesic zone; 3 - fluvial xeric zone.

nomenclature Nyholm (1979), Szafran (1961) and Smith (2004). Voucher specimens are available at the Herbarium Universitatis Lodziensis (LOD-L). Photos are made by author.

\section{RESULTS AND DISCUSSION}

The lichen biota in freshwater habitats is formed of 23 species; they are often accompanied by bryophytes and, sporadically, by red alga Hildenbrandia rivularis growing together with Hydropunctaria rheitrophila. The majority of lichens are epilithic species, but there is a significantly smaller participation of epiphytic lichens. The species of Verrucaria genus are particularly numerous in this habitat (Tab. 2).

Freshwater lichens are mainly noted in the initial parts of rivers and streams (Fig. 1), which is probably a result of the increase in water pollution in further parts of the river. These waters are weakly-acidic to slightly alkaline ( $\mathrm{pH}$ 6.46-7.7) and are well saturated with oxygen. (Tab. 1; see also Ziułkiewicz, Żelazna-Wieczorek 2007a, b).

Similar conditions exist in the waters of streams in the Polish Tatra Mountains, e.g., pH 6.5-8.3 (Krzewicka, Galas 2006).

Freshwater lichens are very sensitive to changes in their habitats and therefore are considered to be the good biological indicators of water purity (cf. Gilbert, Giavarini 1997; Gilbert 2001; Krzewicka 2006).

In examined streams, rivers and spring areas aquatic and semiaquatic crustose lichens grow on 2 types of substrates - on siliceous granite boulders, stones and pebbles, and on the roots of Alnus glutinosa, often covered with sand grains or gravel and silt in the submerged zone, and on bark at the base of trees.

Verrucaria aquatilis, V. hydrela and Hydropunctaria rheitrophila (Fig. 3), 3 typical freshwater lichens colonize siliceous boulders and stones in submerged, fluvial mesic and fluvial xeric zones (Tab. 2). This is frequently observed in the examined streams (Fig. 1). 
Among the freshwater lichens Verrucaria aquatilis and $V$. hydrela are treated as pioneer species, which are first to colonize new substrates; later they are accompanied by Hydropunctaria rheitrophila on the vertical surface of rocks (Keller 2005; Krzewicka, Galas 2006; Krzewicka, Hachułka 2008; Thüs, Schultz 2009). These species are tolerant to a wide range of exposure and moderate eutrophic conditions, and silting in fast running streams. Hydropunctaria rheitrophila is sensitive to silting. This one grows associated with red alga Hildenbrandia rivularis in Kamienna stream. In the investigated streams this red alga was earlier noted also by Żelazna-Wieczorek and Ziułkiewicz (2008).

Verrucaria margacea - amphibious on siliceous boulders - grows in submerged and fluvial xeric zones (Tab. 2).

Amphibious Verrucaria madida occurs in submerged zones only, on inundated granite stones in shaded situation of springs area of the Młynówka stream. $\mathrm{V}$. madida from this locality (Fig. 1) was presented as a new species for Polish biota (Krzewicka, Hachułka 2008).

As for Verrucaria praetermissa (Fig. 5) - it grows on small boulders in periodically inundated zone 2., associated with $V$. funckii and on stones in sporadically inundated (rather by splash water) zone 3. together with Verrucaria aquatilis and Thelidium aquaticum. This species is sensitive to atmospheric conditions as well as to water acidification and restricted to watercourses with $\mathrm{pH}>5$. It is tolerant to silting and eutrophication (Thüs, Schultz 2009).

Furthermore, Verrucaria funckii and $V$. dolosa (a terrestrial species but also amphibious of small streams) occur only in zone 2. Verrucaria funckii is a characteristic element of permanently submerged communities in clean springs and headwaters, and is sensitive to silting and acidification (Thüs, Schultz 2009).

Only in fluvial xeric zone, on stones and boulders were following the crustose epilithic lichens were observed: Bacidina inundata, Porina chlorotica, Thelidium aquaticum, Verrucaria subdolosa, V. muralis and V. murina (Tab. 2).

Bacidina inundata - amphibious by the splash water in shaded places. The species is tolerant to moderate eutrophication but also sensitive to atmospheric acidification (Thüs, Schultz 2009). Porina chlorotica - a terrestrial species on siliceous stone of bridges in shaded and humid places by splash water. Thelidium aquaticum and Verrucaria sublobulata - amphibious in a streams on granite of bridge. According to Thüs and Schultz (2009) V. sublobulata can also rarely grow on roots of alders.

The results of the studies show that the obligatory freshwater crustose lichens reveal in the streams a tendency to move and colonize the secondary substrate, the roots of $A$. glutinosa growing on the stream banks, in the submerged and seasonally submerged zones. In both zones, the alder roots are occupied by Hydropunctaria rheitrophila (Fig. 4). In $2^{\text {nd }}$ zone the alder roots are also colonized by V. aquatilis (cf. Tab. 2).

In lowland Poland, freshwater epilithic lichens growing on the roots of trees are known only from the Białowieża National Park (NE Poland) - Verrucaria hydrela, on submerged roots of $A$. glutinosa in the Orłówka stream (Czyżewska et al. 2001) and from the Wzniesienia Łódzkie Landscape Park (Central Poland) - V. aquatilis in the Młynówka stream (Krzewicka, Hachułka 2008).

Such links are also known in the rivers of Lithuania (Motiejūnaitè 2003, 2009; Motiejūnaitè, Czyżewska 2008). On the roots of Alnus glutinosa and sporadically 


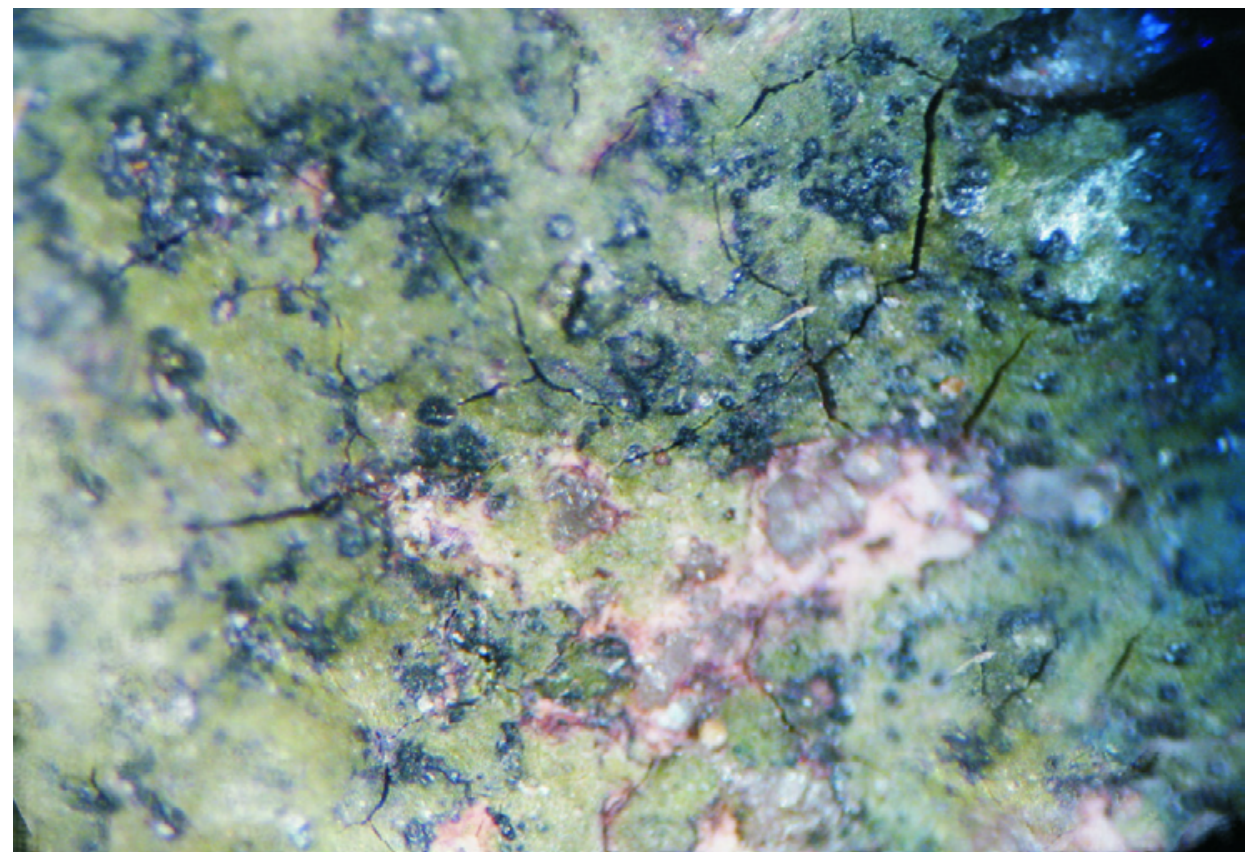

Fig. 3. Hydropunctaria rheitrophila colonizes submerged stones or stones splashed by water (LOD-L 15260).

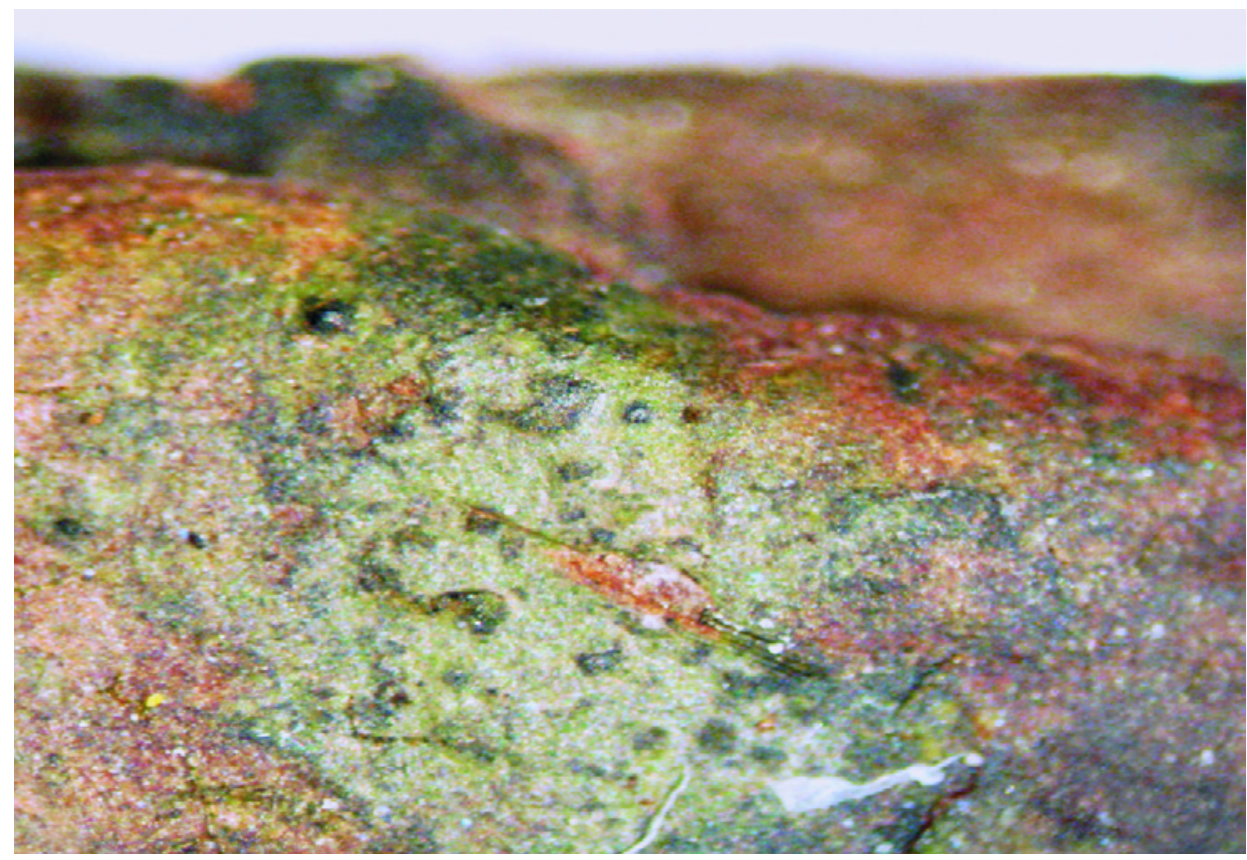

Fig. 4. Hydropunctaria rheitrophila on the bark of Alnus glutinosa roots in fluvial mesic zone (LOD-L 14228). 


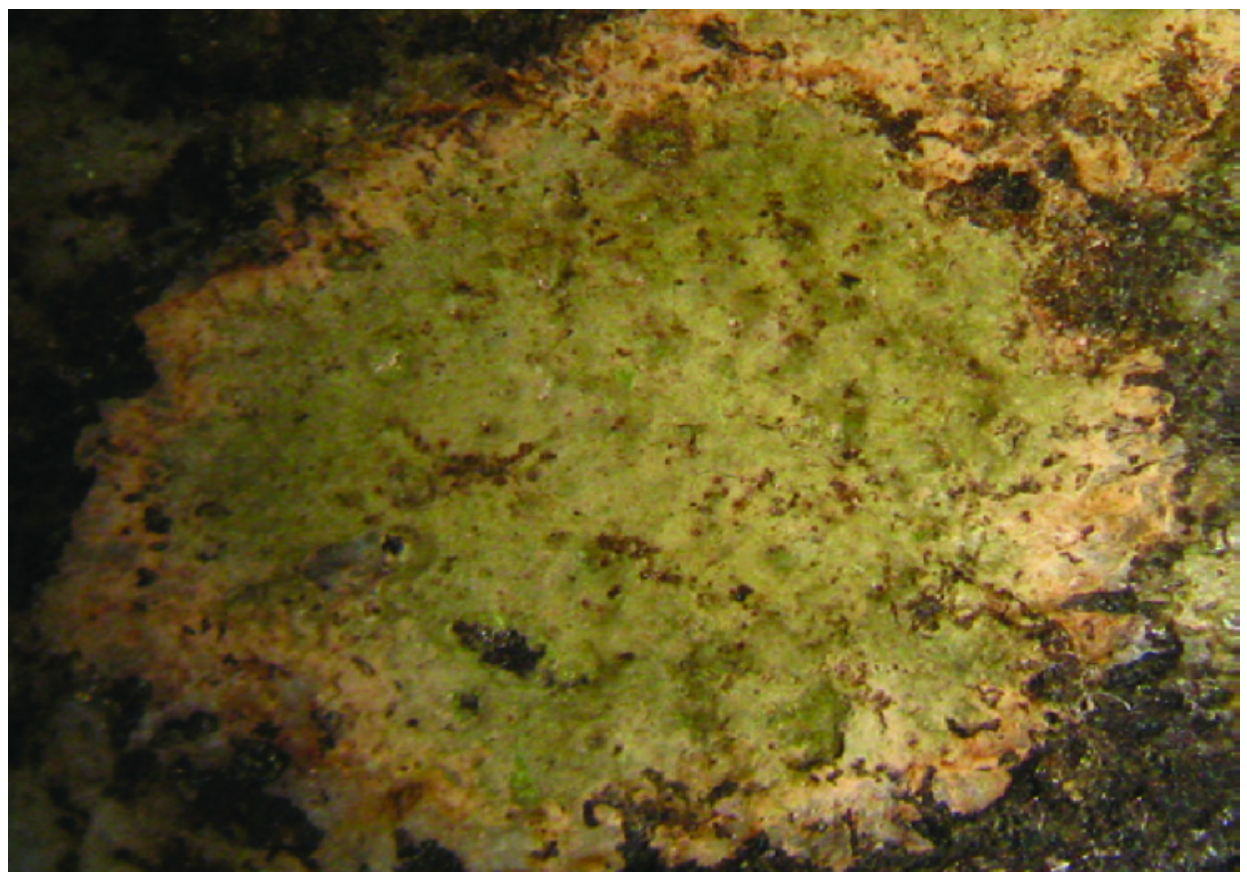

Fig. 5. Verrucaria praetermissa colonizes the stones (LOD-L 14348).

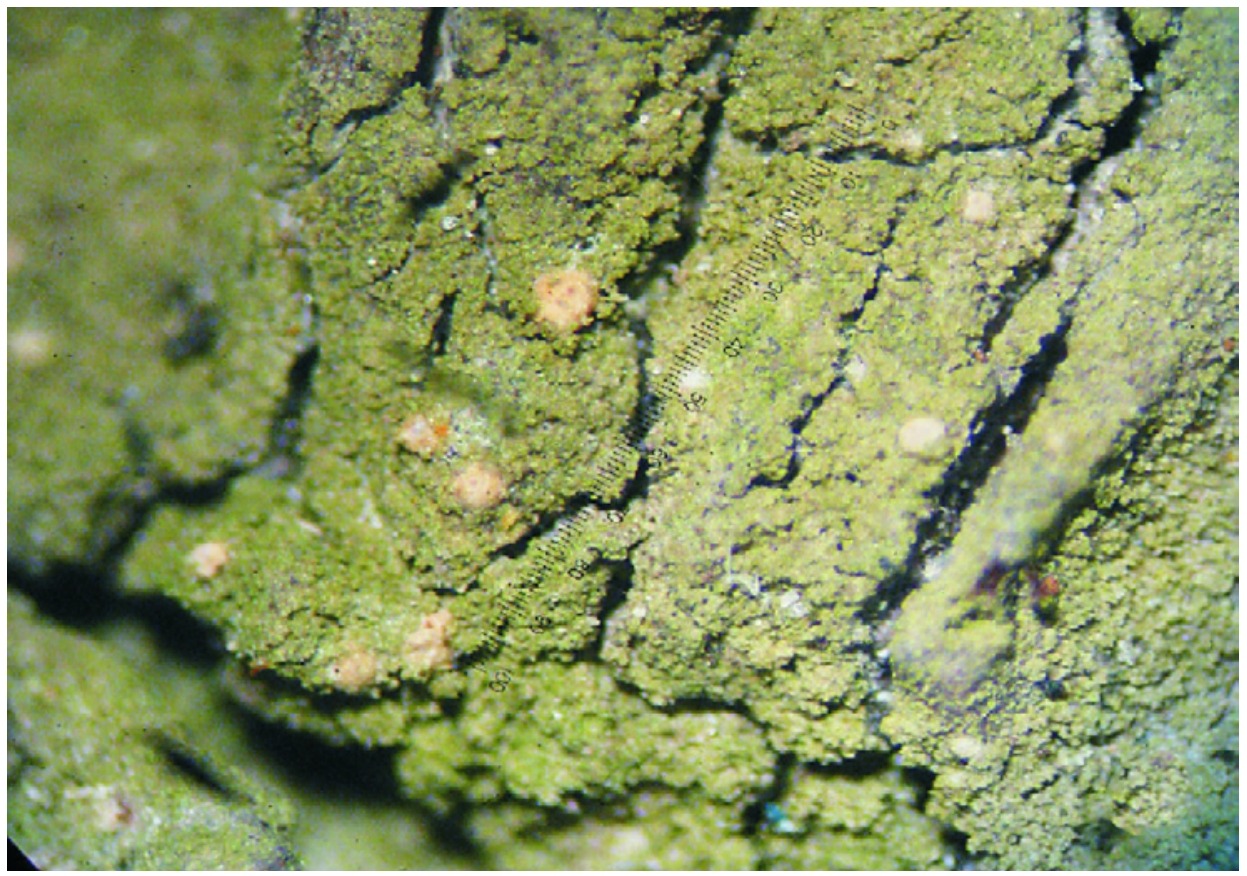

Fig. 6. Bacidina sulphurella with characteristic pycnidia, colonizes the base of the trunk bark of Alnus glutinosa, growing in fluvial xeric zone (LOD-L 14445). 
Table 2

Lichen and bryophyte species growing in streams on stones and boulders (A) and on alder roots and at the base of alder trunks (B) and numbers of their localities

\begin{tabular}{|c|c|c|c|c|c|c|}
\hline \multirow{3}{*}{ Lichen and bryophyte species } & \multicolumn{6}{|c|}{ Zones of submerged stones and alder roots } \\
\hline & \multicolumn{2}{|c|}{$\begin{array}{c}\text { Submerged } \\
\text { zone }\end{array}$} & \multicolumn{2}{|c|}{$\begin{array}{l}\text { Fluvial mesic } \\
\text { zone }\end{array}$} & \multicolumn{2}{|c|}{$\begin{array}{c}\text { Fluvial } \\
\text { xeric zone }\end{array}$} \\
\hline & A & B & A & B & A & $\mathrm{B}$ \\
\hline \multicolumn{7}{|l|}{ Lichens } \\
\hline $\begin{array}{l}\text { Hydropunctaria rheitrophila (Zschacke) Keller, } \\
\text { Gueidan \& Thüs }\end{array}$ & 2 & 1 & 2 & 3 & 1 & . \\
\hline Verrucaria aquatilis Mudd & 1 & & 1 & 1 & 3 & . \\
\hline Verrucaria hydrela Ach. & 2 & . & 3 & . & 3 & . \\
\hline Verrucaria margacea (Wahlenb.) Wahlenb. & 1 & & 1 & & & \\
\hline Verrucaria praetermissa (Trevis.) Anzi & & & 1 & . & 1 &. \\
\hline Verrucaria madida Orange & 1 & . & & . & . & \\
\hline Verrucaria funckii (Spreng.) Zahlbr. & & . & 1 & . & . & . \\
\hline Verrucaria dolosa Hepp & . & & 1 & . & & $\cdot$ \\
\hline Verrucaria sublobulata Eitner ex Servit & . & . & . & . & 1 & . \\
\hline Thelidium aquaticum Serv. & . & & & . & 2 & . \\
\hline Bacidina inundata (Fr.) Vězda & . & & & . & 1 & $\dot{0}$ \\
\hline Candelariella vitellina (Hoffm.) Müll. Arg. & . & . & . & . & 1 & . \\
\hline Physcia caesia (Hoffm.) Fürnr. & $\dot{\theta}$ & & & 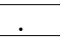 & 1 & . \\
\hline Porina chlorotica (Ach.) Müll. Arg. &. & & . &. & 1 & . \\
\hline Verrucaria muralis Ach. & . & . & . & . & 1 & . \\
\hline Verrucaria murina Leight. & . & & . & & 1 & \\
\hline Arthonia spadicea Leight. & & & & 3 & & 4 \\
\hline Bacidina sulphurella (Samp.) M. Hauck \& V. Wirth & . & . & . & 1 & . & 3 \\
\hline $\begin{array}{l}\text { Coenogonium pineti (Schrad. ex Ach.) Lücking } \\
\& \text { Lumbsch }\end{array}$ & . & $\cdot$ & . & 4 & . & 8 \\
\hline Absconditella lignicola Vězda \& Pišút & & & & 2 &. & . \\
\hline Lecanora conizaeoides Cromb. & . & . & . & 2 & . & \\
\hline Physcia stellaris L. Nyl. & & & & 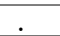 & 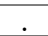 & 1 \\
\hline Trapeliopsis granulosa (Hoffm.) Lumbsch & & & & & & 1 \\
\hline Sum of lichens & 5 & 1 & 7 & 7 & 12 & 5 \\
\hline \multicolumn{7}{|l|}{ Bryophytes } \\
\hline $\begin{array}{l}\text { Brachythecium rivulare Schimp. in Bruch, Schimp. } \\
\text { \& W.Gümbel }\end{array}$ & 1 & . & & . & 1 & 1 \\
\hline Amblystegium juratzkanum Schimp. & & & 1 & $\dot{\square}$ & 1 & 1 \\
\hline Crotoneuron filicinum (Hedw.) Spruce & 2 & . & & . & . & . \\
\hline $\begin{array}{l}\text { Brachythecium salebrosum (Hoffm. ex F.Weber } \\
\& \text { D. Mohr) Schimp. in Bruch, Schimp. \& W.Gümbel }\end{array}$ & . & . & 1 & . & . & . \\
\hline Hygroamblystegium tenax (Hedw.) Jem. &. & $\cdot$ &. & $\dot{\theta}$ & 1 & . \\
\hline $\begin{array}{l}\text { Brachythecium rutabulum (Hedw.) Schimp. in Bruch, } \\
\text { Schimp. \& W.Gümbel }\end{array}$ & $\cdot$ & & & . & 2 & \\
\hline $\begin{array}{l}\text { Brachytheciastrum velutinum (Hedw.) Ignatov } \\
\text { \& Huttunen }\end{array}$ & $\cdot$ & . & & . & . & 1 \\
\hline Sum of bryophytes & 2 & $\mathbf{0}$ & 2 & $\mathbf{0}$ & 4 & 3 \\
\hline
\end{tabular}

on Ulmus sp. and Fraxinus excelsior in submerged zone Verrucaria hydrela, V. praetermissa and Bacidina inundata are growing; in fluvial mesic zone - Thelidium zwackhii, V. hydrela, V. praetermissa, Bacidina inundata and Porina chlorotica, and in fluvial xeric zone 15 species of epiphytic lichens are growing, including Bacidina arnoldiana (Körb.) V. Wirth \& Vězda, which probably belongs to Bacidina sulphurella (Samp.) M. Hauck \& V. Wirth, and Lecania prasinoides Elenkin.

According to Thüs and Schultz (2009) vascular plants do not usually compete with lichens for space. Alder (Alnus glutinosa) and willows (Salix spp.) are occasionally colonized by crustose freshwater lichens. In areas where larger boulders 
are rare, this substrate can be the most important habitat for amphibious lichens (Motiejūnaitè 2003).

Epiphytic growth of freshwater lichens on the roots of vascular plants is more often observed in the Alps (Thüs, Schultz 2009) and in North-Eastern and Eastern Europe (Motiejūnaitė 2003, 2009; Pykälä 2006; Motiejūnaitė, Czyżewska 2008) but is a rare phenomenon in most areas of Central Europe (Thüs, Schultz 2009).

On alders in 2. and 3. inundated zones (Fig. 2) 6 species of epiphytic lichens and 1 epixylic lichen - Absconditella lignicola are growing (Tab. 2). An interesting species in this group is Bacidina sulphurella [= Bacidia arnoldiana var. corticola Arnold, Woessia fusarioides D. Hawksw., Poelt \& Tscherm.-Woess] (Fig. 6). In the study area this species is characterized by pycnidia numerous, white, $0.1-0.25 \mathrm{~mm}$ diam., conidia filiform (24-)25.6-33.0 × $1.6 \mu \mathrm{m}, 0-$ to 3-septate, slightly curved, always with at least one extremity strongly hooked (like a walking stick), apothecia not seen (Brand et al. 2009; Coppins, Aptroot 2009).

Bacidina sulphurella growing on bark at the base of $A$. glutinosa is associated with Absconditella lignicola (only in $2^{\text {nd }}$ zone), Arthonia spadicea and Coenogonium pineti (Tab. 2). According to Coppins and Aptroot (2009) this taxon is tolerant of urban conditions.

So far B. sulphurella was reported from a few scattered localities in Poland: the Góry Sowie Mts and Puszcza Knyszyńska Forest (Brand et al. 2009), Warszawa, „Las Bielański" forest reserve (Kubiak et al. 2010) and the Carpathians - the Gorce Mts (Czarnota 2010), and the Pogórze Wiśnickie foothills (Śliwa 2010).

\section{CONCLUSIONS}

In springs and in initial parts of streams and rivers of the escarpment zone of Wzniesienia Łódzkie Heights 23 species of lichens were noted (cf. Tab. 2), 6 of them, closely connected with water, epilithic species are on the red list of threatened lichens of Poland (Cieśliński et al. 2006): VU category - Hydropunctaria rheitrophila, Verrucaria aquatilis and V. hydrela, NT category - V. praetermissa, and DD category - Thelidium aquaticum and $V$. sublobulata (Figs 1, 3, 4, 5, 6), which indicate the very poor extent of study of these habitats in lowland Poland.

The distribution of freshwater lichens in examined streams shows patent zonality. The least numerous, consisted of the epilithic, obligatory freshwater crustose lichens is the submerged zone (see Tab. 2). The most abounding in species is fluvial xeric zone, consisted mostly of facultative, epilithic and epiphytic lichens noted not only on the wet substrate. Similar links have also been observed in the rivers of Lithuania (Motiejūnaitė 2003).

In the Wzniesienia Łódzkie Landscape Park only Verrucaria aquatilis and $H y$ dropunctaria rheitrophila colonize stones and boulders and submerged roots of $\mathrm{Al}$ nus glutinosa. In the Białowieża National Park in submerged alder roots Verrucaria hydrela was noted (Czyżewska et al. 2001). In the rivers of Lithuania secondary substrates are colonized by 5 epilithic species: Bacidina inundata, Porina chlorotica, Thelidium zwackhii, Verrucaria hydrela and V. praetermissa (Motiejūnaitė 2003, 2009). 
The lichens growing in the investigated streams compete with bryophytes (mosses and liverworts) for substrate. Together on boulders in streams and on the stream banks 7 species of bryophytes were noted, the most of them in sporadically inundated zone 3 (see also Tab. 2). The zonal occupying of the substrates probably exists also among the bryophytes.

The lichens, as well as the bryophytes, connected with water habitats in the Polish lowlands need further wide-ranging studies.

Acknowledgements. The author would like to thank Prof. Krystyna Czyżewska (University of Łódź) for entrusting the interesting subject of the study, for her assistance and support during the preparation of the manuscript, Dr Beata Krzewicka (Polish Academy of Sciences, Kraków) - for identification and revision of freshwater lichens, especially critical species of the genus Verrucaria, Dr Monika Staniaszek-Kik (University of Łódź) - for identification of bryophyte species, Dr. Zbigniew Kaczkowski (University of Łódź) - for carring out physicochemical studies of the waters of Kamienna and Grzmiąca streams. The studies were partially supported by the Ministry of Science and Higher Education - grant No. N 305043 32 and grants of University of Łódź Nos 505/396 and 505/413/W.

\section{REFERENCES}

Bielczyk U. 2003. The lichens and allied fungi of the Polish Carpathians - an annotated checklist. W. Szafer Institute of Botany, Polish Academy of Sciences, Kraków, 342 pp.

Brand M., Coppins B., van den Boom P. P. G., Sérusiaux E. 2009. Further data on the lichen genus Bacidia s.l. in the Canary Island and Western Europe, with descriptions of two new species. Bibliotheca Lichenologica 99: 81-92.

Bujakiewicz-Grabowska E., Magnuszewski A. 2002. Przewodnik do ćwiczeń z hydrologii ogólnej. Warszawa, 195 pp.

Cieśliński S., Czyżewska K., Fabiszewski J. 2006. Red list of the lichens in Poland. (In:) Z. Mirek, K. Zarzycki, W. Wojewoda, Z. Szeląg (eds). Red list of plants and fungi in Poland. W. Szafer Institute of Botany, Polish Academy of Sciences, Kraków: 71-89.

Coppins B. J., Aptroot A. 2009. Bacidia De Not. (1846). (In:) C. W. Smith, A. Aptroot, B. J. Coppins, A. Flechter, O. L. Gilbert, P. W. James and P. A. Wolseley (eds). The lichens of Great Britain and Ireland. The British Lichen Society: 189-207.

Coste C. 2010. New ecology and new classification for phytosociology of hydrophilic lichens in acid wa-

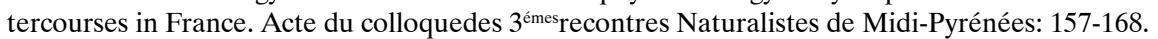

Czarnota P. 2000. Porosty Gorczańskiego Parku Narodowego. Część I. Wykaz i rozmieszczenie gatunków. Parki nar. Rez. Przyr. 19 (1): 3-73.

Czarnota P. 2010. Critical list of lichens and lichenicolous fungi of the Gorce Mts. Ochrona Beskidów Zachodnich 3: 55-78.

Czyżewska K., Cieśliński S., Motiejūnaitė J., Kolanko K. 2002. The Budzisk nature reserve as a biocentre of lichen diversity in the Knyszyńska Large Forest (NE Poland). Acta Mycol. 37 (1/2): 77-92.

Czyżewska K., Motiejūnaitė J., Cieśliński S. 2001. Species of lichenized and allied fungi new to Białowieża Large Forest (NE Poland). Acta Mycol. 36 (1): 13-19.

Diederich P., Ertz D., Stapper N., Sérusiaux E., Van den Broeck D., van den Boom P., Ries C. 2011. The lichens and lichenicolous fungi of Belgium, Luxembourg and northern France. URL: http:// www.lichenology.info [date of exploration 21 Sept. 2011].

Fałtynowicz W. 2003. The lichens, lichenicolous and allied fungi of Poland - an annotated checklist. W. Szafer Institute of Botany, Polish Academy of Sciences, Kraków, 435 pp.

Fałtynowicz W., Kukwa M. 2006. Lista porostów i grzybów naporostowych Pomorza Gdańskiego. Acta Bot. Cassubica. Monographiae 2: 1-98.

Fałtynowicz W., Marcinkiewicz E., Rutkowski P. 2000. Porosty rezerwatu „Dolina Zagórskiej Strugi” koło Rumii na Pojezierzu Kaszubskim. Acta Botanica Cassubica 1: 119-126.

Flakus A. 2007. Lichenized and lichenicolous fungi from mylonitized areas of the subnival belt in the Tatra Mounains (Western Carpathians). Ann. Bot, Fennici 44: 427-449.

Gilbert O. L. 1996. The lichen vegetation of chalk and limestone streams in Britain. Lichenologist 28 (2): $145-159$. 
Gilbert O. L. 2001. Freshwater habitats. (In:) A. Fletcher (ed.). Lichen habitat management, p. 08-1-08-3.

Gilbert O. L. Giavarini V. J. 1997. The lichen vegetation of acid watercourses in England. Lichenologist 29 (4): 347-367.

Gueidan C., Savič S., Thüs H., Roux C., Keller C., Tibell L., Prieto M., Heiðmarsson S., Breuss O., Orange A., Fröberg L., Wynns A. A., Navarro-Rosinés P., Krzewicka B., Pykälä J., Grube M., Lutzoni F. 2009. Generic classification of the Verrucariaceae (Ascomycota) based on molecular and morphological evidence: recent progress and remaining challanges. Taxon 58 (1): 184-208.

Hachułka M. 2007. Porosty naskalne w środowisku przyrodniczym Parku Krajobrazowego Wzniesień Łódzkich. (In:) E. Kępczyńska, J. Kępczyński (eds). Botanika w Polsce - sukcesy, problemy, perspektywy. Streszczenia referatów i plakatów 54. Zjazdu Polskiego Towarzystwa Botanicznego. Szczecin: 132 .

Hauck M., Wirth V. 2010. New combinations in Bacidina. Herzogia 23 (1): 15-17.

Hawksworth D. L. 2000. Freshwater and marine lichen-forming fungi. (In:) K. D. Hyde, W. H. Ho, S. B. Pointing (eds). Aquatic Mycology across the Millenium. Fungal Diversity 5: 1-7.

Keller Ch. 2005. Artificial substrate colonized by fresh water lichens. Lichenologist 37 (4): 357-362.

Kiszka J. 1967. Porosty Beskidu Śląskiego. Roczniki Nauk Dydaktycznych, WSP w Krakowie 28: 5-91.

Kiszka J. 1985. Porosty Pogórza Spiskiego. Studia Ośrodka Dokumentacji Fizjogr. PAN 7: 349-377.

Kiszka J. 1995. Porosty brzegów i koryt potoków w zlewni Czarnej Wisełki i Białej Wisełki. (In:) S. Wróbel (ed.). Zakwaszenie Czarnej Wisełki i eutrofizacja zbiornika zaporowego. Instytut Biologii, Wyższa Szkoła Pedagogiczna: 81-85.

Kiszka J. 1996. Nowe i rzadkie gatunki porostów (Lichenes) w Bieszczadzkim Parku Narodowym. 1. Roczniki Bieszczadzkie 5: 43-48.

Kiszka J. 1997. Porosty (Lichenes) dna i otoczenia zbiorników retencyjnych w dolinie Dunajca w Pieninach. Fragm. Flor. Geobot. Polonica 4: 253-323.

Kiszka J. 1998. The Lichens of stream banks and beds in the Czarna Wisełka and Biała Wisełka catchments. Studia Naturae 44: 113-123.

Kiszka J. 2000. Nowe dla Pienin gatunki porostów. 2. Fragm. Flor. Geobot. Polonica 7: 277-279.

Kiszka J., Kościelniak R. 2001. Nowe i rzadkie gatunki porostów (Lichenes) w Bieszczadzkim Parku Narodowym i jego otulinie. 3. Roczniki Bieszczadzkie 9 (2000): 27-32.

Kondracki J. 2000. Geografia regionalna Polski. PWN, Warszawa, 440 pp.

Kościelniak R. 2004. Porosty (Lichenes) Bieszczadów Niskich. Fragm. Flor. Geobot. Polonica, Supplementum 5: 1-164.

Kościelniak R., Kiszka J. 2003. The lichens and allied fungi of the Polish Eastern Carpathians. (In:) U. Bielczyk (ed.). The lichens and allied fungi of the Polish Carpathians - an annotated checklist. W. Szafer Institute of Botany, Polish Academy of Sciences, Kraków: 233-294.

Kozik R. 1977. Porosty (Lichenes) Pogórza Rożnowsko-Ciężkowickiego. Fragm. Flor. Geobot. 23 (2): 215-252.

Krzewicka B. 2006. Wodne gatunki porostów z rodzaju Verrucaria w potoku Chochołowskim w Tatrach. (In:) Z. Mirek, B. Godzik (eds). Tatrzański Park Narodowy na tle innych górskich terenów chronionych. Nauki biologiczne 2, Zakopane: 51-56.

Krzewicka B. 2009. Some new records of Verrucaria from Beskid Niski Mts. Acta Mycol. 44 (2): $265-273$.

Krzewicka B., Galas J. 2006. Ecological notes on Verrucaria aquatilis and V. hydrela in the Polish Tatry Mauntains. (In:) A Lackovičovà, A. Guttovà, E. Lisickà, P. Lizoň (eds). Central European lichens diversity and threat, p.193-204, Mycotaxon Ltd., Ithaca.

Krzewicka B., Hachułka M. 2008. New and interesting records of freshwater Verrucaria from Central Poland. Acta Mycol. 43 (1): 91-98.

Kubiak D., Wrzosek M., Zaniewski P. 2010. Materiały do bioty porostów i grzybów naporostowych rezerwatu „Las Bielański” w Warszawie. Parki nar. i Rez. Przyr. 29 (3): 3-15.

Kukwa M. 2000. Porosty i grzyby naporostowe zachodniej części Pojezierza Iławskiego (Polska północna). Fragm. Flor. Geobot. Polonica 7: 281-297.

Lipnicki L. 2002. Porosty rezerwatu „Dolina Rzeki Brdy” w Tucholskim Parku Krajobrazowym. (In:) M. Ławrynowicz, B. Rózga (eds). Tucholski Park Krajobrazowy 1985-2000 - stan poznania. Wyd. Uniwersytetu Łódzkiego, Łódź: 368-384.

Moniewski P. 2004. Źródła okolic Łodzi. Acta Geogr. Lodz. 87: 1-140.

Motiejūnaitė J. 2003. Aquatic lichens in Lithuania. Lichens on submerged alder roots. Herzogia 16: 113-121. 
Motiejūnaite J. 2009. Lichens and allied fungi of two Regional Parks in Vilnius area (Lithuania). Acta Mycol. 44 (2): 185-199.

Motiejūnaitė J., Czyżewska K. 2008. Additions to the biota of lichens and lichenicolous fungi of Poland, with a note on Lecania prasinoides in Eastern and Central Europe. Polish Bot. J. 53 (2): 155-162.

Nowak J. 1965. Porosty Beskidu Małego. Fragm. Flor. Geobot. 11 (3): 209-242.

Nowak J. 1967. Porosty Wyżyny Wieluńskiej. Acta Mycol. 3: 209-242.

Nowak J. 1998. Porosty Beskidów Wyspowego i Żywieckiego, Pasma Jałowca i Masywu Babiej Góry. Monogr. Bot. 83: 1-131.

Nowak J. Tobolewski Z. 1975. Porosty Polskie. PWN, Kraków, 1177 pp.

Nyholm E. 1979. Illustrated moss flora of Fennoscandia. II. Musci. Fasc. 5. $2^{\text {nd }}$ edition. Swedish Natural Science Research Council, Sweden: 405-647.

Pykälä J. 2006. Additions to the lichen flora of Finland. Graphis Scripta 18: 41-48.

Smith A. J. E. 2004. The Moss Flora of Britain and Ireland. $2^{\text {nd }}$ ed. Cambridge University Press, United Kingdom, 1012 pp.

Smith C. W., Aptroot A., Coppins B. J, Flechter A., Gilbert O. L., James P. W., Wolseley P. A. 2009. The lichens of Great Britain and Ireland. The British Lichen Society, 1046 pp.

Szafran B. 1961. Mchy (Musci). Flora Polska. Rośliny zarodnikowe Polski i ziem ościennych. 2. Państwowe Wydawnictwo Naukowe, Warszawa, 405 pp.

Szczepańska K. 2008. Antropogeniczne przemiany bioty porostów Masywu Śnieżnika i Gór Bialskich. Acta Bot. Silesiaca, Monographiae 4: 1-291.

Szymczyk R. 2007. Rzadkie i interesujące gatunki porostów i grzybów naporostowych na Wysoczyźnie Elbląskiej (Północna Polska). Fragm. Flor. Geobot. Polonica 14 (1): 167-173.

Szymczyk R., Zalewska A. 2008. Lichenbiota of the Grabianka river valley in the Elbląg Upland (Wysoczyzna Elbląska). Pol. J. Natur. Sci. 23 (2): 398-414.

Śliwa L. 2010. Contribution to the lichen biota of the Pogórze Wiśnickie foothills (Carpathians). Acta Mycol. 45 (2): 219-230.

Thüs H., Schultz M. 2009. Fungi. 1. $1^{\text {st }}$ Part: Lichens. (In:) B. Büdel, G. Gärtner, L. Krienitz, H.-R. Preisig, M. Schagerl (eds). Freshwater Flora of Central Europe. Spectrum Akademischer Verlag, Heidelberg, $223 \mathrm{pp}$.

Walisch M. 2007. Zasilanie źródłowe małych zlewni regionu łódzkiego na tle przepuszczalności utworów powierzchniowych. (In:) P. Jokiel, P. Moniewski, M. Ziułkiewicz. Żródła Polski. Wybrane problemy krenologiczne. Wydz. Nauk Geogr. UŁ, Łódź: 153-162.

Ziułkiewicz M. 1999. Chemizm wód źródlanych Parku Krajobrazowego Wzniesień Łódzkich. (In:) E. Biesiadki, S. Czachorowski (eds). Żródła Polski - stan badań, monitoring i ochrona. Wyższa Szkoła Pedagogiczna, Olsztyn: 249-252.

Ziułkiewicz M., Żelazna-Wieczorek J. 2007a. Różnorodność okrzemek w wodach źródlanych o różnym stopniu przekształcenia hydrochemicznego. (In:) Z. Michalczyk (ed.). Badania hydrograficzne w poznawaniu środowiska. Obieg wody w środowisku naturalnym i przekształconym. Wyd. Uniw. Marii Curie-Skłodowskiej, Lublin: 592-599.

Ziułkiewicz M., Żelazna-Wieczorek J. 2007b. Okrzemki bentosowe żródła Dobieszków na tle warunków siedliskowych. (In:) P. Jokiel, P. Moniewski, M. Ziułkiewicz (eds). Źródła Polski. Wybrane problemy krenologiczne. Wydz. Nauk Geogr. UŁ, Łódź: 265-279.

Żelazna-Wieczorek J., Ziułkiewicz M. 2008. Hildenbrandia rivularis (Rhodophyta) in Central Poland. Acta Soc. Bot. Pol. 77 (1): 41-47. 

Słodkowodne porosty na zanurzonych kamieniach i korzeniach olsz
na Niżu Polskim

\section{Streszczenie}

W rzekach i strumieniach Parku Krajobrazowego Wzniesień Łódzkich, w Polsce Środkowej, odnotowano 23 gatunki porostów wodnych (Tab. 2), z którymi konkuruje o podłoże 7 gatunków mszaków. Sześć ściśle wodnych gatunków naskalnych znajduje się na czerwonej liście porostów zagrożonych Polski (Cieśliński et al. 2006). Większość porostów wodnych rośnie w odcinkach początkowych rzek i strumieni, co prawdopodobnie wynika z korzystnych warunków fizykochemicznych wód (Tab. 1) i wzrostu zanieczyszczenia w dalszym biegu rzek. Badania porostów wodnych wykazały ich rozmieszczenie w trzech strefach: 1 - całkowicie zatopionej, 2 - często zatapianej i 3 - sporadycznie zatapianej lub spryskiwanej wodą (Fig. 2). W drugiej i trzeciej strefie zanurzenia, w towarzystwie Coenogonium pineti, Arthonia spadicea i Absconditella lignicola (Tab. 2) rośnie Bacidina sulphurella (Fig. 5), rzadki porost w Polsce.

$\mathrm{W}$ badanych rzekach obligatoryjne epility wodne rosną na głazach i kamieniach, jedynie Hydropunctaria rheitrophila (Figs 3 A, B) i Verrucaria aquatilis zasiedlają także korę korzeni olsz często pokrytych ziarnami piasku i mułem. Kolonizowanie podłoży zastępczych przez epility wodne obserwowano w Alpach (Thüs and Schultz 2009), w północno-wschodniej i wschodniej Europie (Motiejūnaitė 2003, 2009; Pykälä 2006; Motiejūnaitė, Czyżewska 2008), również w Polsce Północno-Wschodniej (Czyżewska et al. 2001). 